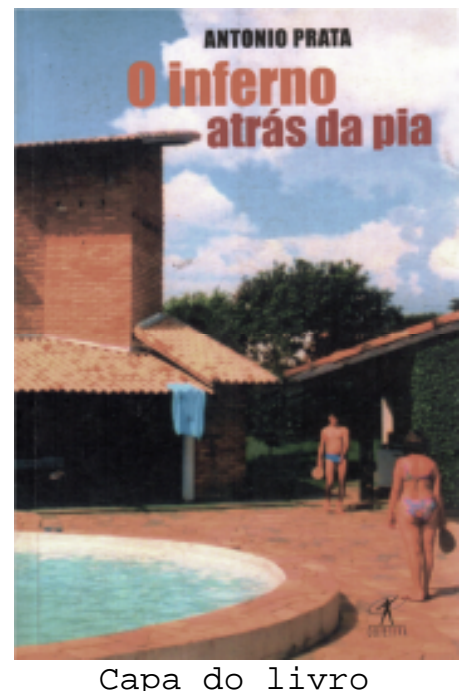

\title{
o inferno atrás da pia
}

\section{Juliana Helena Gomes Leal}

Doutoranda em Literatura Comparada, FALE/UFMG. Mestre em Estudos Literários e professora de Língua Portuguesa e Língua Espanhola.

PRATA, Antônio. 0 inferno atrás da pia. Rio de Janeiro: Objetiva, 2004. 109 p.

Dificil ficar alheio aos textos do jovem escritor paulista Antônio Prata. Para o bem e para o mal.

Apesar de se chamar a atenção, no prefácio de o inferno atrás da pia (aliás, é preciso destacar que as apresentações de seus livros são verdadeiras obras-primas), para a "sacanagem" cometida por Cervantes em ter se apoderado de "praticamente todas as idéias disponíveis na face da Terra para compor sua novela, obrigando os escritores do futuro a se digladiarem em torno de umas migalhas de invenção", o leitor dos textos de Antônio Prata poderá estar seguro de que ele transformará essas "migalhas" em curiosas narrativas.

Exemplos? No texto "Coisas", há uma constatação: "Embora não entenda o código cifrado do mundo das coisas, tenho certeza de que elas não apenas se comunicam entre si, mas também querem passar algumas mensagens para nós, humanos". Em "Debaixo de nossos narizes: livre tratado de semiótica experimental", um dos melhores trechos do livro, há um filosofar sobre barbas, bigodes e cavanhaques que não deixa dúvidas sobre o talento de 
Prata para tecer esdrúxulas elucubrações: "A barba funciona como uma espécie de proteção entre a pessoa e o mundo" $e$, talvez, "seja o dejeto das idéias".

Acompanhar as peripécias, os dramas e os pequenos prazeres experenciados pelo ser humano nas páginas de "Lapa 875C", "Sentou no chiuaua e foi ao cinema" ou "O sentido da vida" pode levar o leitor a dar boas gargalhadas ou, sendo menos eufórica em minhas previsões, a emitir sorrizinhos, por timidez ou em razão de uma desconcertante identificação. Trata-se da redução da distância entre literatura e recepção possibilitada pela implicação do leitor com aquilo que lê (por pura diversão ou pelo acesso inconsciente aos arquivos de sua memória pessoal): o prazer do texto para o deleite do leitor.

Ação dentro da palavra, a escrita de Prata ganha plasticidade graças a toques certeiros de ironia e humor e a uma aguçada criticidade que desnuda eus enunciativos (ficcionais e reais) por semantizar situações das mais absurdas - embora perfeitamente compreensíveis - tais como a encontrada no texto "Édipo S.A.", por exemplo. Nele, acompanharemos um diálogo entre duas crianças "prafrentíssimas", "no tanquinho de areia de uma escola bilíngue", que discutem as vantagens em se privatizar as mães.

Para os mais afoitos - duvido que não haja outros como eu - em marcar encontros com textos semelhantes aos reunidos nas páginas de O inferno atrás da pia, aí vão duas super dicas que podem acrescentar aos favoritos de seu computador. Em www.digestivocultural.com/ensaios/ensaio.asp?codigo=225, você encontrará um texto deliciosamente crítico sobre aqueles que adoram fazer o tipo "meio intelectual, meio de esquerda", mas que gostam mesmo é de bar ruim. Esse texto, sem dúvida alguma, vai levá-lo ao blog oficial do escritor, www.blogdoantonioprata.blogspot.com, a partir do qual você poderá se deleitar com inúmeros contos e crônicas de prata e ainda deixar comentários sobre as impressões que você teve ao lê-los.

Assim é Antonio Prata: um escritor que não poupa ninguém! Nem Deus, acreditem! Mas pra contar essa história, eu teria que resenhar Douglas e outras histórias: seu livro de 2001. Se você quiser se antecipar... 